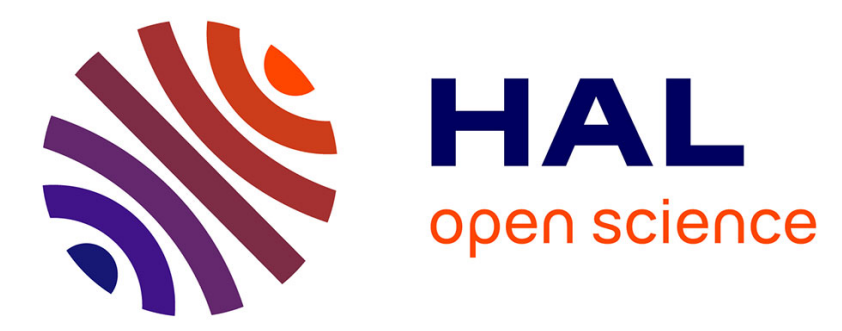

\title{
Production of green juice with an intensive thermo-mechanical fractionation process. Part I: Effects of processing conditions on the dewatering kinetics
}

Patricia Arlabosse, Marion Blanc, S Kerfaï, Arnaud Fernandez

\section{- To cite this version:}

Patricia Arlabosse, Marion Blanc, S Kerfaï, Arnaud Fernandez. Production of green juice with an intensive thermo-mechanical fractionation process. Part I: Effects of processing conditions on the dewatering kinetics. Chemical Engineering Journal, 2011, 168 (2), pp.586-592. 10.1016/j.cej.2011.01.027 . hal-01165222

\section{HAL Id: hal-01165222 \\ https://imt-mines-albi.hal.science/hal-01165222}

Submitted on 18 Jun 2015

HAL is a multi-disciplinary open access archive for the deposit and dissemination of scientific research documents, whether they are published or not. The documents may come from teaching and research institutions in France or abroad, or from public or private research centers.
L'archive ouverte pluridisciplinaire $\mathbf{H A L}$, est destinée au dépôt et à la diffusion de documents scientifiques de niveau recherche, publiés ou non, émanant des établissements d'enseignement et de recherche français ou étrangers, des laboratoires publics ou privés. 


\title{
PRODUCTION OF GREEN JUICE WITH AN INTENSIVE THERMO- MECHANICAL FRACTIONATION PROCESS. PART I: EFFECTS OF PROCESSING CONDITIONS ON THE DEWATERING KINETICS
}

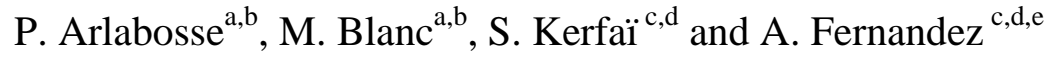 \\ a Université de Toulouse; Mines Albi; CNRS ; Campus Jarlard, F-81013 Albi, France. \\ ${ }^{\mathrm{b}}$ Ecole des Mines Albi, Centre RAPSODEE, Campus Jarlard, F-81013 Albi, France. \\ ${ }^{c}$ Université de Toulouse ; INSA, UPS, INP ; LISBP, 135 Avenue de Rangueil, F-31400 \\ Toulouse, France \\ ${ }^{\mathrm{d}}$ INRA, UMR792 Ingénierie des Systèmes Biologiques et des Procédés, F-31400 Toulouse, \\ France \\ ${ }^{\mathrm{e}}$ CNRS, UMR5504, F-31400 Toulouse, France \\ Corresponding author: Patricia.Arlabosse@mines-albi.fr, \\ tel: +33 5634932 37, fax: +33563493243
}

\begin{abstract}
The thermally assisted mechanical dewatering (TAMD) process is a new intensive solid/liquid separation device. When applied to 'nature-wet' biomass, the TAMD process significantly enhances the separation yield. The TAMD process couples in one stage a mechanical dewatering at low pressure $\left(\mathrm{P}_{\text {applied }}=300 \mathrm{kPa}\right.$ in the present study $)$ with a moderated heating $\left(\mathrm{T}_{\text {wall }} \leq 90^{\circ} \mathrm{C}\right)$. An increment of pressure can be applied in a second stage
\end{abstract}


to further enhance the dry solid content of the press cake. In the present study, the TAMD process was used to dewater spinach leaves and alfalfa stems and leaves. The influence of cutting, pulping and temperature on the fractionation kinetics and the extraction yield were specifically investigated. Experiments were carried out on a laboratory compression cell, heated through the piston. Results shows that, at ambient temperature, pulping is an essential pre-processing unit operation to reach an extraction yield of $55 \%$. Under moderate heating conditions $\left(\mathrm{T}_{\text {wall }}=50\right.$ or $\left.70^{\circ} \mathrm{C}\right)$, a thermally assisted mechanical dewatering, without any preprocessing stage, can remove $69 \%$ of the inherent water from alfalfa, that is to say an increase by $23 \%$ of the yield. But, compared with the conventional fractionation process, the duration of the mechanical fractionation must be at least twice longer. Beyond $70^{\circ} \mathrm{C}$, the temperature does not have any influence on the extraction kinetics. Cutting has a very limited influence with an enhancement of the dry solid content from 2 to $5 \%$ at best.

Keywords: Pressing, Heating, Biomass, Press-cake, Maceration, Leaves.

\section{Introduction}

Sustainable development requires the use of renewables as alternative feedstocks for chemical, fuel and material productions. Share of renewable raw materials in the US feedstock consumption runs to approximately $5 \%$ in the chemical industry and is expected to increase notably and to reach $25 \%$ by 2030 [1]. The same tendency is impelled by the European governments, but targets were exclusively defined for energy purposes [2]. To face this challenge, the concept of biorefinery was set up [3]. The underlying idea is to maximize the value derived from renewable feedstocks by producing a variety of chemicals, fuels and intermediates or end-products, using well integrated, environment- and resource-friendly technologies [4]. To guarantee an optimal exploitation of the various components in biomass, processing routes are defined according to the organic compositions of the raw materials. 
Taking this into account, five biorefinery systems are commonly considered [5]: whole crop, green, oilseed, forest-based and, more recently, waste biorefineries. Systems based on agricultural crops raised some social and ecological criticisms recently. To avoid any competition with food, the ideal feedstock is nowadays considered to be residual by-products accumulated in abundance and with low or no profit and nutritional value [6]. These includes classically food and feed crop residues, wood residues, herbaceous plants, grasses, leaves and stems. The latter are still hardly used in spite of their large availability, their high biomass profit per hectare and their good coupling with agricultural production.

These 'nature-wet' raw materials require a fast primary processing or the use of preservation methods, like silage or drying. But due to the energy consumption of thermal dryer, the biomass is seldom transformed after drying, so that mechanical fractionation of the wet material is usually the first unit operation in a green biorefinery plant. The vegetative biomass is separated into a fiber-free extract containing the protoplasmic fluid - the green juice - and a fiber-rich solid fraction - the press cake. Both fractions have an economic value. The green juice is a raw material for high quality fodder proteins, cosmetic proteins, human nutrition or platform chemicals like lactic acid and lysine $[7,8,9,10,11]$ or can be used as substrate for biogas production [12]. The press cake can be used as fodder pellets after thermal drying [13], as silage feed [11] or as solid fuel [14]. Conventional technologies for juice extraction involve mechanical pulping to disintegrate the cell walls followed by pressing [15], possibly with multistage addition of water and expression following the first pressing [16]. Most of the time, pressing is carried out with a screw press to provide additional maceration of the cell walls in complement of the action of the pressure. For vegetative biomass like alfalfa, clover and grass, screw presses remove approximately 55-60\% of the inherent liquid $[11,15]$.

To date, the economic viability of green biomass fractionation process, for instance the ProXan-Process [17] used to produce a marketed leaf protein concentrate, depends, to a large 
extent, on the utilization of the solid fraction as a high quality ruminant feed $[15,18]$. The emergence of biorefineries, with further alternative processing routes especially for the nutrient-rich liquid fraction, can make the wet fractionation process more profitable [11]. Consequently, there is a lot of research at present into methods that enhance the dewatering ability of conventional mechanical processes. Intensification of mechanical dewatering processes can take several forms: simultaneous application of a pulsed electric field [19, 20], superimposition of ultrasounds [21, 22] or with heat supply [23]. The underlying objectives are to obtain a juice in larger quantity [24] and of better quality. In the same time, other works relate to the processes of fractionation of the juice. The green juice is usually subjected to a differential coagulation to get the protein-rich chloroplastic fraction, containing almost all the extracted lipids and lipid-associated pigments, and the cytoplamic fraction containing the soluble proteins, like the Rubisco, with very small amount of lipids and pentosans. Conventional techniques include differential fractionation of the extracts by heat, centrifugation or $\mathrm{pH}$ adjustment, or with solvents, polyelectrolytes or other reagents, or by a combination of some of these techniques. Until now, there is no simple and economical method for isolating large quantities of plant enzymes even if nanofiltration and ultrafiltration [25] or expanded-bed chromatography [26, 27] seem to produce good performances on a laboratory scale.

At all events, the initial fractionation of the biomass remains an essential operation for biorefinery process. For a few years now, we specifically investigate a thermally assisted mechanical dewatering (TAMD) process [28], which couples a mechanical dewatering with a simultaneous moderate heating of the walls of the apparatus in contact with the product. Thermal mechanical dewatering method is not a brand new technology [23, 29-31] but the operating conditions of the TAMD process and its use for the mechanical fractionation of the herbaceous biomass are quite innovating. The compression is carried out in two step: a first 
compression stage at low pressure (usually $300 \mathrm{kPa}$ ) and a second stage around $1500 \mathrm{kPa}$. The TAMD process was used to effectively dewater alfalfa biomass under a variety of processing conditions ranging from 21 to $90^{\circ} \mathrm{C}$ and from 300 to $3000 \mathrm{kPa}$ [24]. It has been illustrated that it can remove up to $83 \%$ of the inherent liquid fraction from alfalfa under moderate processing conditions, which is a much higher extraction yield than in conventional mechanical dewatering process. The TAMD process is thus likely to extract a green juice in larger quantity than with conventional fractionation processes. Now, the operating conditions of the TAMD process, especially the influence of the temperature, on the extraction kinetics and the green juice quality has to be investigated, in order to evaluate its potential of valorization and optimize the TAMD process accordingly. This paper is the first of a series of two papers, which explores the TAMD biomass fractionation procedure when applied to typical 'nature-wet' biomass, addressing the following questions:

1. To what extent does the mechanical fractionation with the TAMD process result in a separation among a fiber-free liquid extract and a fiber-rich solid fraction ?

2. Is pulping necessary to enhance the amount of green juice recovered?

3. Compared to conventional mechanical fractionation procedure, what is the efficiency of the TAMD process?

After a short description of the experimental device and the materials used for the mechanical fractionation experiments in section 2 , the influence of a prior cutting and of the heating conditions are analyzed in section 3. The efficiency of the TAMD process is assessed in section 4 and compared to the one of a conventional mechanical fractionation process. Finally, the optimal conditions for the separation are given as concluding remarks. 


\section{Materials and methods}

\subsection{Experimental set up}

At the laboratory scale, the experimental set up consists of a compression cell inserted in a CARVER $^{\circledR}$ hydraulic press (Carver Inc., Wabash, United State), which has a maximum pressing capacity of $14800 \mathrm{kPa}$ and provides the pressure required to progress a downward expression.

The cell (Figure 1) consists of a compressive piston, a hollowed cylindrical vessel and a filter medium. The filtration chamber has a diameter of $148 \mathrm{~mm}$ and a maximum height of $60 \mathrm{~mm}$. In spite of its low mechanical resistance, Teflon ${ }^{\mathrm{TM}}$ was selected as constitutive material of the vessel walls to minimize the frictions with the piston. Consequently, a stainless steel external jacket is added to ensure the mechanical resistance of the unit. The cell is fitted with a planar medium, made of Teflon ${ }^{\mathrm{TM}}$, of $165.2 \mathrm{~cm}^{2}$ area. To investigate the influence of a heat supply, three electric resistances are inserted in the upper part of the compressive piston, made of copper to reduce thermal inertia. Each resistor can supply up to 350W. Three thermocouples, including the one for the temperature regulation of the copper block, are introduced into the piston. The accuracy of these sensors with theirs acquisition line is estimated at $\pm 0.03^{\circ} \mathrm{C}$. 


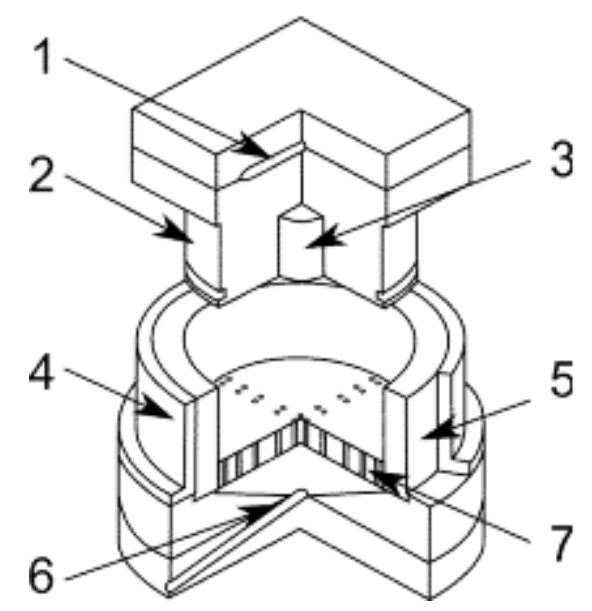

Figure 1 - Detail of the experimental cell. (1) Electric resistance; (2) Copper piston; (3)

Fluxmeter; (4) Steel jacket; (5) Teflon vessel; (6) Filtrate collector; (7) Filter medium

\subsection{Feed materials}

The composition of the liquid fraction is influenced by a multiplicity of factors operating during the whole process, beginning with the agronomic factors (plant species, spacing, fertilizers, climate...) and the pre-pulp conditions (maturity of the vegetation, harvesting and post-harvesting environment...). Moreover, it is well-known that the chloroplasts contribute to a large extent to the total leaf protein (up to $75 \%$ for photosynthetically active leaves) and that the Rubisco, which is located within the chloroplasts, is the most abundant soluble protein in photosynthetic organs. This enzyme catalyses the first step of the metabolic pathway found in the stroma of the chloroplast in which carbon enters in the form of $\mathrm{CO}_{2}$ and leaves in the form of sugar. Partially purified powder of Rubisco from spinach leaves, available in large amounts as a lyophilised powder with stable activity, can be bought from the chemical trade. Thus, to develop the analytical methods for the green juice characterization [32] and to investigate the influence of the TAMD fractionation procedure on the green juice composition, we selected spinach as a reference biomass. Alfalfa was selected as a second feed material according to its industrial use [17]. 


\subsubsection{Spinach}

Fresh winter spinaches (Spinacia oleracea) were bought in a small independent store, having a short circuit of provisioning. Fresh spinaches in bulk were preferred to packaged one, whose water content is higher because of a pre-wash before packaging. The fresh leaves were stored in a tight container at $4^{\circ} \mathrm{C}$ to avoid the desiccation of the plant, in accordance with the storage protocol already developed [24]. After 7 days, the dry solid content of the biomass remained unchanged and, visually, neither yellowing nor fading were observed. From the beginning of February to mid-April, six batches of spinach leaves were bought. The wet-basis moisture content of the leaves ranged between 88.3 and $90.9 \%$, according to the batch. Dewatering experiments were carried out in the week following the purchase. About $240 \mathrm{~g}$ of fresh spinach leaves were introduced into the TMAD process. In a same batch, the size of the leaves was very variable, from 5 to $12 \mathrm{~cm}$ long and from 4 to $10 \mathrm{~cm}$ broad. To investigate the influence of the size on the fractionation kinetics, three physical "structures" were considered: the whole leaves, the leaves chopped into pieces of $3 \times 3 \mathrm{~cm}$ and the leaves chopped into 0.5 cm broad bands.

\subsubsection{Alfalfa}

Alfalfa, also known as Lucerne, is a perennial legume, in the pea family Fabaceae, widely grown throughout the world as forage for cattle and harvested as hay. Alfalfa has the highest feeding value of all common hay crops, with high protein content and highly digestible fiber. Grown on well-drained soils with neutral $\mathrm{pH}$, total yield is commonly around 8 tons per hectare but can reach up to $15-20$ tons per hectare. The plant is very resilient to droughts, thanks to its deep root system. Moreover, its root nodules contain bacteria with the ability to fix nitrogen. In most climates, alfalfa is cut 3 to 4 times a year. Alfalfa (Medicago sativa L.) was field-chopped at the pre-blossoming stage. Approximately 300 to $500 \mathrm{~mm}$ long fresh stems with leaves were sampled at weekly intervals between mi-May and mid-June 2010. The 
fresh alfalfa was transported to the laboratory and stored at $4^{\circ} \mathrm{C}$ in a tight container within $1 \mathrm{~h}$ after the harvest. The wet basis moisture content of the fresh alfalfa ranged between $78.4 \%$ and $82.6 \%$, according to the week of sampling. Dewatering experiments were carried out in the three days following the harvest. About $200 \mathrm{~g}$ of fresh alfalfa were chopped into 5-cm pieces before introduction into the TAMD process.

\subsection{Experimental procedures}

Previous studies [24, 33] emphasized that the dewatering enhancement for biomass results only from thermal effects. As a consequence, the influence of the pressure applied was not investigated in the present study. The mechanical fractionation protocol was as follows. The biomass was introduced at room temperature into the TAMD device. At $t=0$, a pressure of $300 \mathrm{kPa}$ was applied through the compressive piston, previously heated at the selected operating temperature. Progressively, the biomass was separated into a green juice and a press cake. The filtrate recovered in the collector flowed out into a container laid on the computer interfaced balance. The applied pressure, the piston temperatures, the temperature of the face of the cake in contact with the filter medium and the mass of filtrate were recorded at set time intervals of $1 \mathrm{~s}$.

At the end of the experiment, the press cake was weighed. Its dry solid content, defined as the weight of the dry sample divided by the weight of the wet sample times 100 , was measured according to the AFNOR standard procedure $\mathrm{N}^{\circ} \mathrm{X} 31-505$. This procedure recommended a drying at $105^{\circ} \mathrm{C}$ for 24 hours. To check that the mass balance was preserved during the experiment, the dry solid content of the initial biomass was determined using the same protocol and the moisture content of the press cake at the end of the experiment was calculated knowing the mass of the juice fraction and compared to the experimental value. The dry solid content, S, and the dry basis moisture content, W, were calculated according to the following equations: 


$$
\begin{aligned}
& S=\frac{m_{\text {dry matter }}}{m_{\text {dry matter }}+m_{\text {liquid }}} \times 100 \\
& W=\frac{m_{\text {liquid }}}{m_{\text {dry matter }}}
\end{aligned}
$$

Observations were carried out to highlight the hydric state of the cells, before and right after the TAMD process has been applied. The plant tissues were fixed with $2.5 \%$ glutaraldehyde $(25 \%)$ in a $0.05 \mathrm{M}$ sodium-cacodylate buffer for an hour. After rinsing and ambient-air drying, the samples were cut into $30 \mu \mathrm{m}$-thick sections with a microtome (MICROM HM 255). Microscopic observations of the samples were then carried out thanks to the optic microscope LEICA DMRB whose magnifying power goes from $\mathrm{x} 100$ to $\mathrm{x} 630$. The microscope is equipped with a black and white camera (MICAM VHR 1000) linked to a television set that transmits the pictures to an acquisition software (Studio Version 8).

\section{Results and discussion}

3.1 Influence of the operating parameters on the TAMD kinetics

\subsubsection{Evaluation of the process repeatability and estimate of the measure accuracy}

Dewatering experiments were repeated at least 4 times with the same process operating conditions to evaluate the repeatability of the results. Dry solid contents achieved at the end of a dewatering experiment performed with a wall temperature of $50^{\circ} \mathrm{C}$ or $70^{\circ} \mathrm{C}$ are reported in Table 1 for spinach leaves chopped into $0.5 \mathrm{~cm}$ broad bands and alfalfa chopped into 5 -cm pieces. The maximum standard deviation on the dry solid content of the dewatered biomass is $\pm 0.8 \%$ for spinach and $\pm 1 \%$ for alfalfa. This uncertainty is in agreement with former results [24]. As can be seen in Table 1, the dispersion introduced by the batch number is more important than that associated with the sampling and the repeatability of the experiment, that can be estimated $\pm 0.55 \%$ for alfalfa. 


\begin{tabular}{|c|c|c|c|c|c|}
\hline \multicolumn{6}{|c|}{ Spinach leaves chopped into $0.5 \mathrm{~cm}$ broad bands } \\
\hline \multicolumn{3}{|c|}{ Wall temperature $=50^{\circ} \mathrm{C}$} & \multicolumn{3}{|c|}{ Wall temperature $=70^{\circ} \mathrm{C}$} \\
\hline $\begin{array}{c}\text { Number of the batch } \\
\text { from which the sample } \\
\text { comes }\end{array}$ & $\begin{array}{c}\text { Initial dry } \\
\text { solid content } \\
(\%)\end{array}$ & $\begin{array}{c}\text { Final dry } \\
\text { solid content } \\
(\%)\end{array}$ & $\begin{array}{c}\text { Number of the batch } \\
\text { from which the sample } \\
\text { comes }\end{array}$ & \begin{tabular}{|c|} 
Initial dry \\
solid content \\
$(\%)$
\end{tabular} & $\begin{array}{c}\text { Final dry } \\
\text { solid content } \\
(\%)\end{array}$ \\
\hline 2 & 10.8 & 24.5 & 1 & 9.9 & 25.4 \\
\hline 4 & 11.7 & 22.8 & 3 & 9.1 & 26.4 \\
\hline 4 & 11.7 & 22.8 & 5 & 9.6 & 24.9 \\
\hline 7 & 8.3 & 23.9 & 7 & 8.3 & 24.7 \\
\hline \multicolumn{2}{|c|}{ Mean value } & 23.5 & \multicolumn{2}{|c|}{ Mean value } & 25.3 \\
\hline \multicolumn{2}{|c|}{ Standard deviation } & 0.8 & \multicolumn{2}{|c|}{ Standard deviation } & 0.8 \\
\hline \multicolumn{6}{|c|}{ Alfalfa leaves and stems } \\
\hline \multicolumn{3}{|c|}{ Wall temperature $=50^{\circ} \mathrm{C}$} & \multicolumn{3}{|c|}{ Wall temperature $=70^{\circ} \mathrm{C}$} \\
\hline $\begin{array}{c}\text { Number of the batch } \\
\text { from which the sample } \\
\text { comes }\end{array}$ & $\begin{array}{c}\text { Initial dry } \\
\text { solid content } \\
(\%)\end{array}$ & $\begin{array}{c}\text { Final dry } \\
\text { solid content } \\
(\%) \\
\end{array}$ & $\begin{array}{c}\begin{array}{c}\text { Number of the batch } \\
\text { from which the sample } \\
\text { comes }\end{array} \\
\end{array}$ & \begin{tabular}{|c|} 
Initial dry \\
solid content \\
$(\%)$
\end{tabular} & \begin{tabular}{|c|} 
Final dry \\
solid content \\
$(\%)$
\end{tabular} \\
\hline 1 & 21.6 & 36.5 & 3 & 17.8 & 36.8 \\
\hline 1 & 21.6 & 37.3 & 5 & 20.3 & 38.1 \\
\hline 4 & 17.5 & 35.1 & 6 & 22.4 & 37.7 \\
\hline 5 & 21.0 & 37.1 & 6 & 22.4 & 37.9 \\
\hline \multicolumn{2}{|l|}{ Mean value } & 36.5 & \multicolumn{2}{|c|}{ Mean value } & 37.6 \\
\hline \multicolumn{2}{|c|}{ Standard deviation } & 1.0 & \multicolumn{2}{|c|}{ Standard deviation } & 0.6 \\
\hline
\end{tabular}

Table 1 - Influence of sampling and processing repeatability on the initial and final dry solid

\author{
contents of the biomass
}

The fractionation kinetics of spinach leaves measured for a wall temperature of $70^{\circ} \mathrm{C}$ are plotted in Figure 2. In spite of the heterogeneity of material (in a given batch) and the various batches, the kinetics are appreciably the same even if, around 750 seconds, the difference in the initial rate of fractionation, highlighted on Figure 2, results in a significant dispersion of the mass of filtrate $( \pm 22 \mathrm{~g})$. The dispersion decreases with time $( \pm 6.1 \mathrm{~g}$ after $5000 \mathrm{~s})$. 


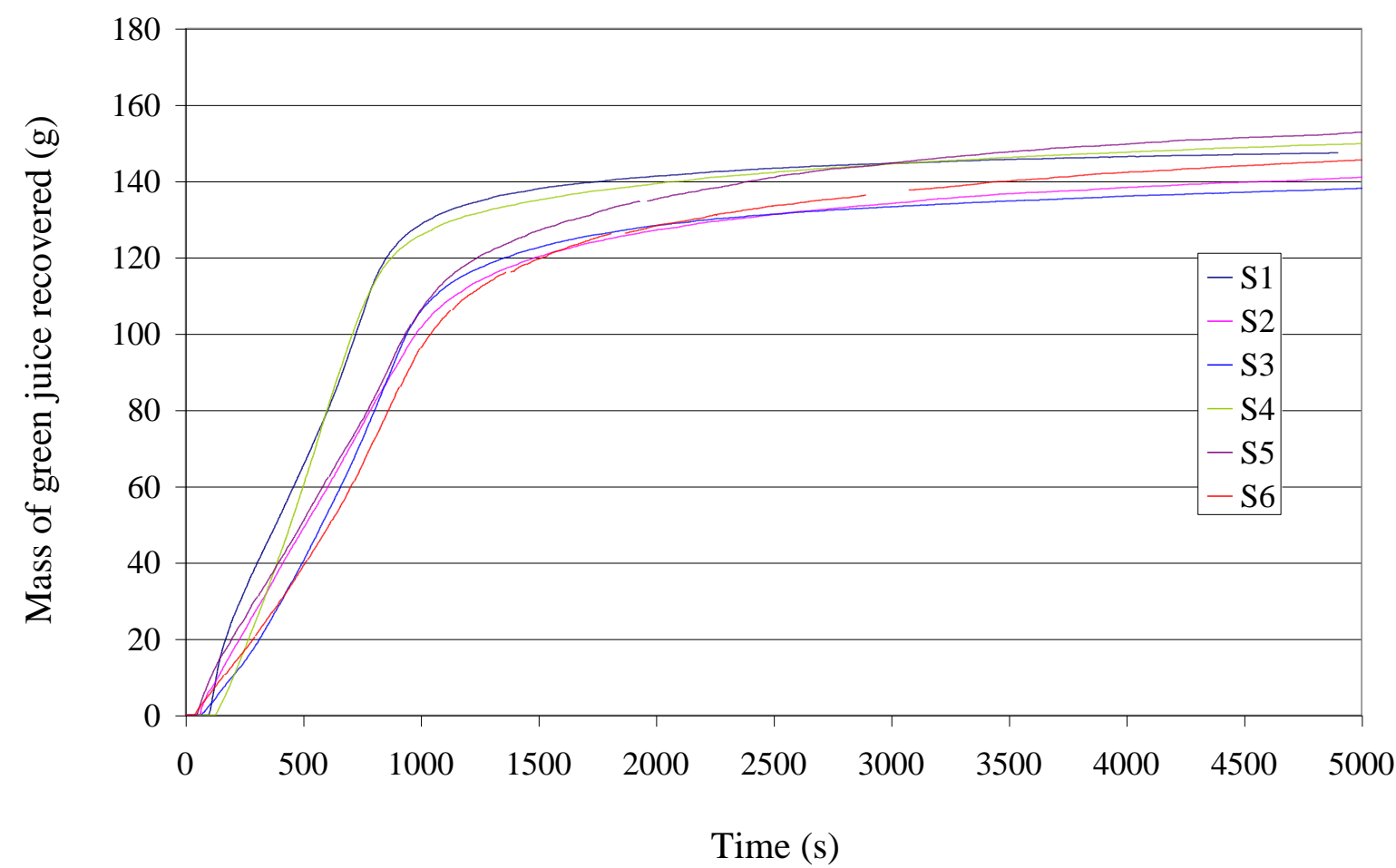

Figure 2 - Repeatability of the experiments with spinach leaves coming from the same

$$
\text { sampling }\left(\mathrm{T}_{\text {piston }}=70^{\circ} \mathrm{C}\right)
$$

\subsubsection{Influence of the cutting on the fractionation kinetics}

Three cuttings were considered for spinach leaves:

- $\quad$ none (whole leaves);

- coarse (leaves chopped into pieces of $3 \times 3 \mathrm{~cm}$ );

- $\quad$ and fine (leaves chopped into $0.5 \mathrm{~cm}$ broad bands).

For each cutting, the fractionation experiments were performed for four wall temperatures, namely $30,50,70$ and $90^{\circ} \mathrm{C}$. Whatever the piston temperature used, the tendency is similar. For example, the average fractionation kinetics obtained with a wall temperature of $70^{\circ} \mathrm{C}$ for the three available cuttings are given on Figure 3. To reduce the measurement uncertainty, the feed material for all the experiments was sampled in the same batch. Thus, according to the process repeatability, the maximum standard deviation on the mass of filtrate is $\pm 3 \mathrm{~g}$. The mass of green juice recovered during the mechanical fractionation increases with the degree 
of cutting, especially when the biomass is cut finely. This result was expected. Indeed, the cutting breaks some cell walls and plasma membranes, releasing the contents of the cytoplasm and more precisely the cytosol, as well as some tonoplasts, releasing the contents of the vacuole $[34,35]$. The cytosol is the portion of a plant cell that is not enclosed within membrane-bound organelles. It is composed of water, salts and organic molecules. The vacuole is a membrane-bound organelle, which could be represented as an enclosed compartment, filled with water containing inorganic and organic molecules. Thus, the preprocessing treatment by cutting makes the liquid fractions in the cell plant more accessible thus facilitates the dewatering.

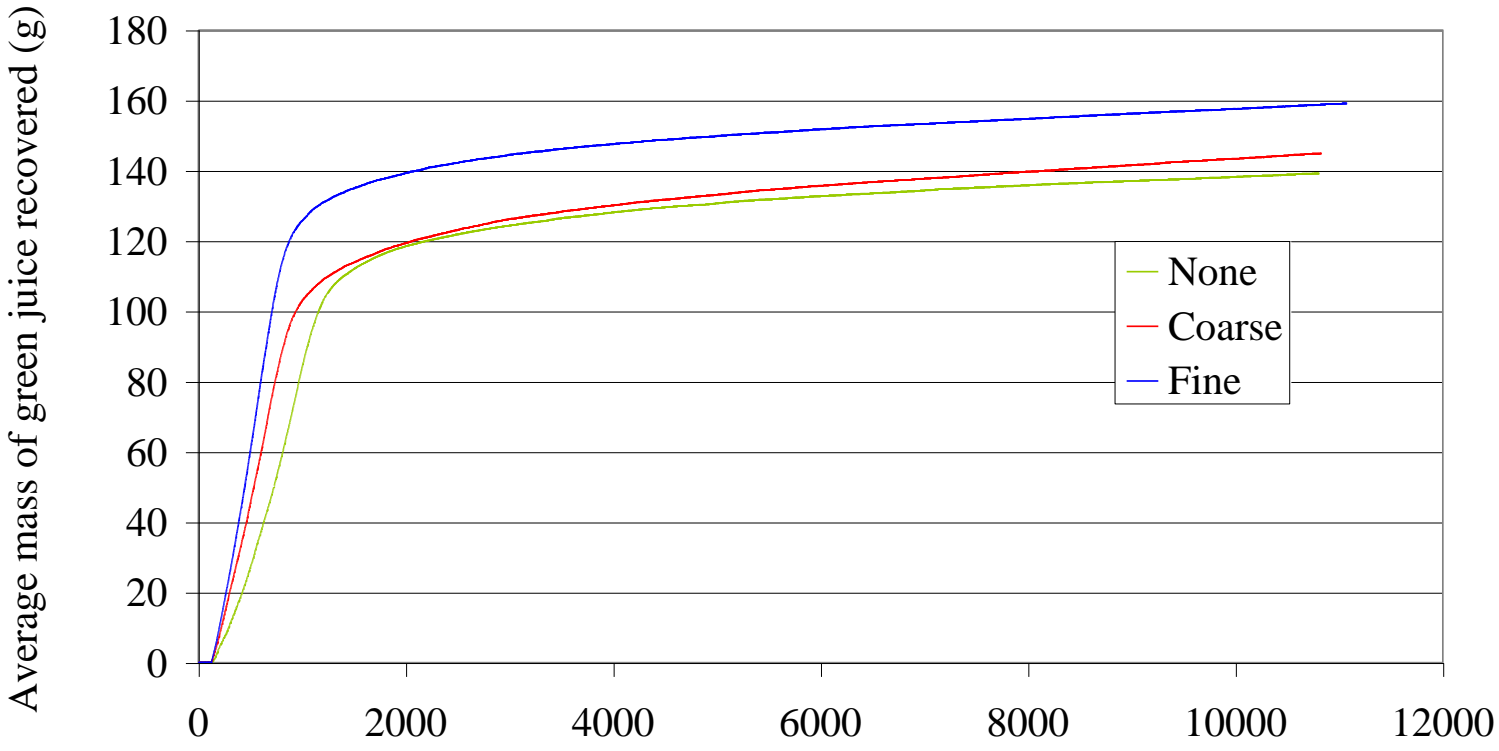

Time (s)

Figure 3 - Influence of cutting on the mechanical fractionation kinetics of spinach leaves

$$
\left(\mathrm{T}_{\text {piston }}=70^{\circ} \mathrm{C}\right) \text {. }
$$

The influence of cutting on the press cake dry solid content is reported in Table 2. According to the measurement uncertainty, the changes observed with a wall temperature set to $30^{\circ} \mathrm{C}$ are not significant, whatever the degree of cutting. Furthermore, for all the wall temperatures investigated, a coarse cutting does not change much the dry solid content of the press cake compared to the value achieved with whole leaves. When the biomass is cut more finely, the 
dry solid content increases more significantly. At best, an increase in the dry solid content from 2 to $5 \%$ can be expected. For a biomass with relatively large leaves, like spinaches, the rupture of the cell walls facilitates the mechanical fractionation of the material: the amount of green juice recovered is larger and consequently the press cake is drier.

\begin{tabular}{|c|c|c|c|}
\cline { 2 - 4 } \multicolumn{1}{c|}{} & None & Coarse & Fine \\
\hline $\mathrm{T}_{\text {wall }}=30^{\circ} \mathrm{C}$ & 11.5 & 11.2 & 11.9 \\
\hline $\mathrm{T}_{\text {wall }}=50^{\circ} \mathrm{C}$ & 19.6 & 21.6 & 23.2 \\
\hline $\mathrm{T}_{\text {wall }}=70^{\circ} \mathrm{C}$ & 23.1 & 23.8 & 25.3 \\
\hline $\mathrm{T}_{\text {wall }}=90^{\circ} \mathrm{C}$ & 31.7 & 31.9 & 37.6 \\
\hline
\end{tabular}

Table 2 - Influence of the cutting and the wall temperature on the final dry solid content

$$
\text { ( in \%) of spinach leaves }
$$

\subsubsection{Influence of heating on the fractionation kinetics}

The influence of heating on the dry solid content of the spinach press cake can be analyzed through the values reported in Table 2. Whatever the degree of cutting, an increase in the piston temperature significantly enhances the dry solid content of the press cake compared to a conventional dewatering at room temperature. At $30^{\circ} \mathrm{C}$, pressing enhances the dry solid content of spinach cake from $9 \%$ to $12 \%$. The dry solid content reaches $25.3 \%$ for a wall temperature of $70^{\circ} \mathrm{C}$ and even $37.6 \%$ for a wall temperature of $90^{\circ} \mathrm{C}$. Thus, the effect of the wall temperature is much more important than the degree of cutting. As can be seen in Figure 4, the dry solid content enhancement, defined as the difference between the dry solid content of the press cake after three hours of processing and the initial dry solid content of the biomass, is linearly proportional to the set temperature $\left(\mathrm{R}^{2}=0.94\right)$. 


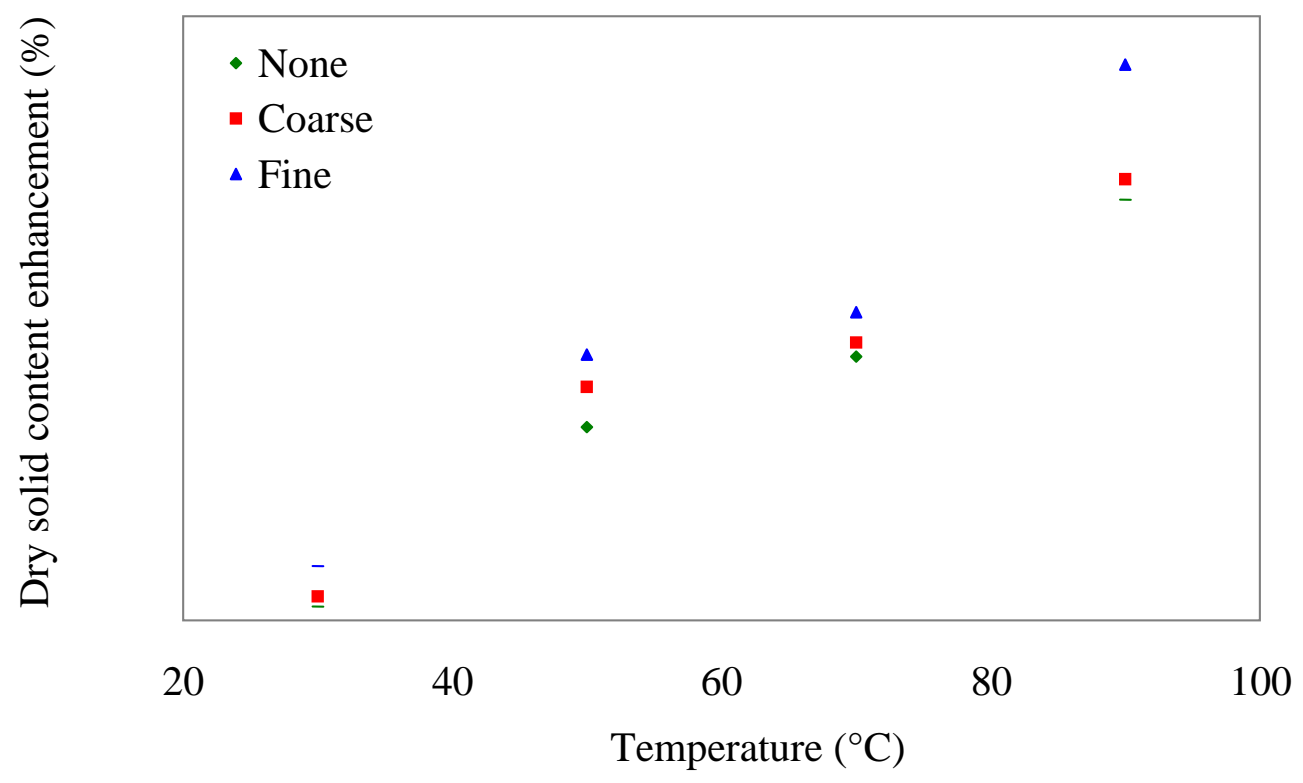

Figure 4 - Influence of the wall temperature on the dry solid content enhancement (compared to the initial dryness) after three hours of processing.

The average fractionation kinetics measured for the four wall temperatures, namely $30,50,70$ and $90^{\circ} \mathrm{C}$, are plotted in Figure 5 (a). Results emphasize that the higher the temperature is, the larger the recovered mass of green juice is (as previously mentioned) and the faster the dewatering is, even if the kinetics of fractionation observed with a wall temperature of $70^{\circ} \mathrm{C}$ or $90^{\circ} \mathrm{C}$ are practically identical. The same behaviours are observed with alfalfa (see Figure 5 (b) for the kinetics and Table 3 for the influence of the heating on the dry solid content). The amount of green juice produced is at least five times larger with a heat supply through the piston wall than with a conventional pressing at ambient temperature and the separation is faster. 


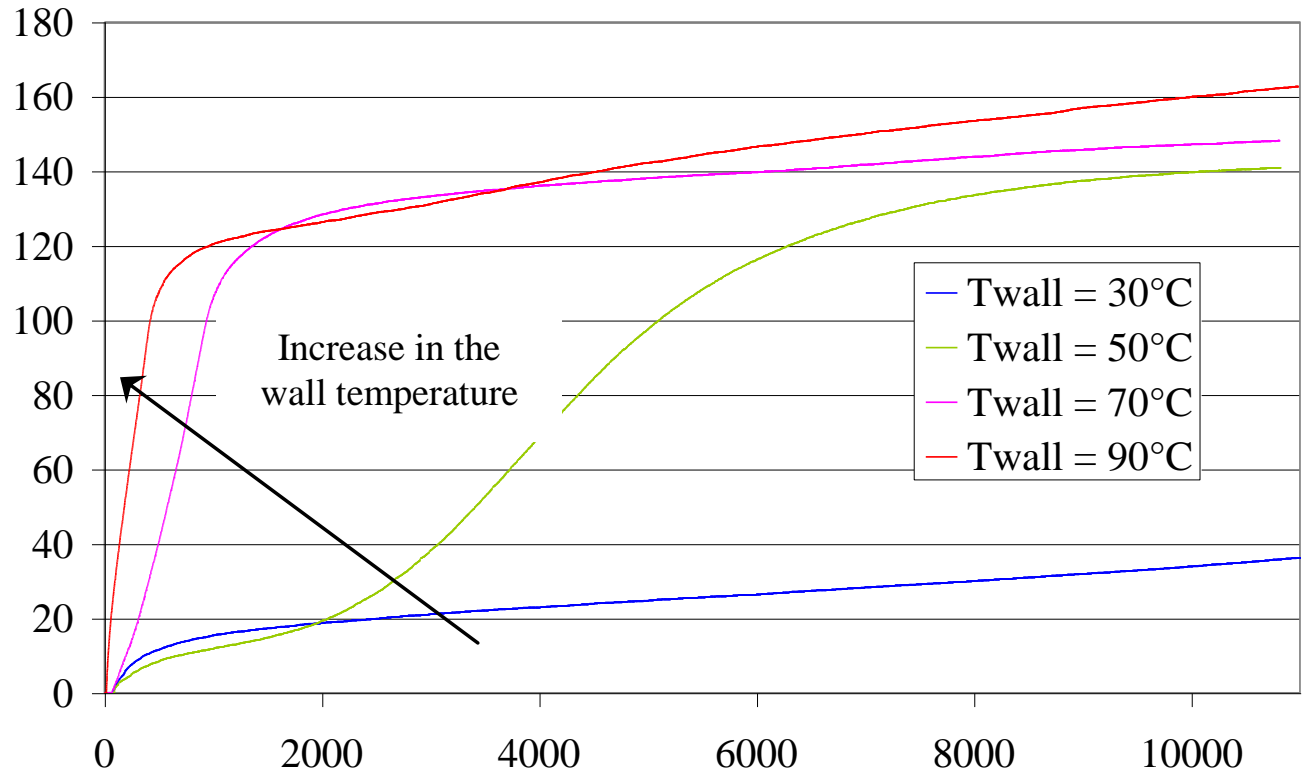

Time (s)

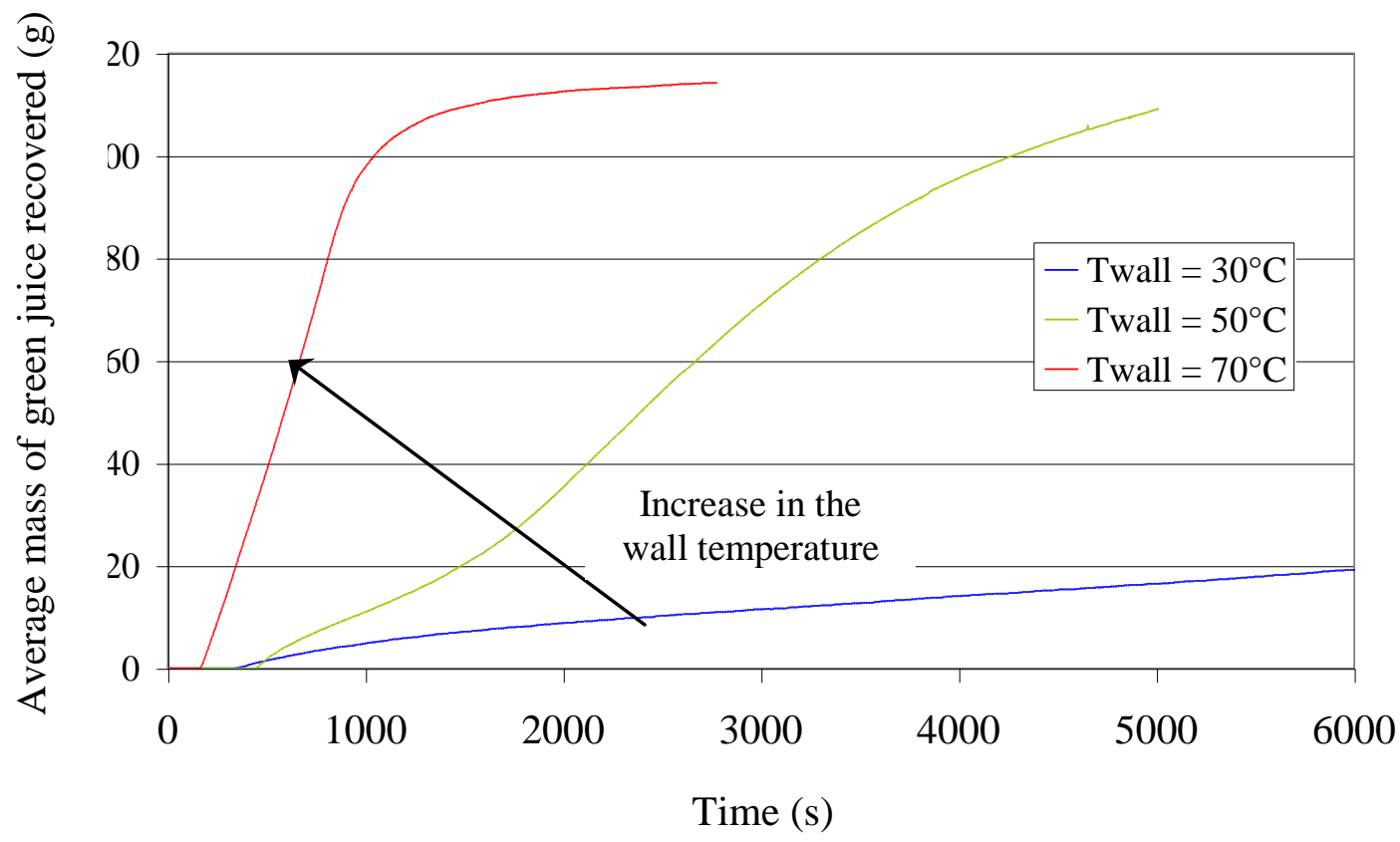

Figure 5 - Influence of the wall temperature on the mechanical fractionation kinetics of spinach leaves (a) or alfalfa $(b)$ 
Compared to the maximum amount available with spinach, the mass of green juice is a little lower but fresh alfalfa was initially drier than spinach leaves. This result is in agreement with the work of Savoie and Beauregard [36], which emphasized that the proportion of green juice increases (from 10 to $21 \%$ ) when the initial wet basis moisture content increases (from 80 to $84 \%$ ). For both materials, the difference between the fractionation kinetics obtained with a wall temperature of $50^{\circ} \mathrm{C}$ or $70^{\circ} \mathrm{C}$ lies primarily in the duration of separation, the total amount of juice recovered being identical according to the measurement repeatability.

\begin{tabular}{|c|c|c|c|}
\cline { 2 - 4 } \multicolumn{1}{c|}{} & $\begin{array}{c}\text { Initial dry solid } \\
\text { content (\%) }\end{array}$ & $\begin{array}{c}\text { Final dry solid } \\
\text { content (\%) }\end{array}$ & $\begin{array}{c}\text { Dry solid content } \\
\text { variation (\%) }\end{array}$ \\
\hline $\mathrm{T}_{\text {wall }}=30^{\circ} \mathrm{C}$ & 17.1 & 19.4 & 2.3 \\
\hline $\mathrm{T}_{\text {wall }}=50^{\circ} \mathrm{C}$ & 17.8 & 34.3 & 16.5 \\
\hline $\mathrm{T}_{\text {wall }}=70^{\circ} \mathrm{C}$ & 17.8 & 36.8 & 19 \\
\hline
\end{tabular}

Table 3 - Influence of the wall temperature on the variation of the dry solid content variation for alfalfa

One possible explanation of the role of temperature lies in the phenomenon of osmosis. Osmosis is the movement of water molecules across a partially permeable membrane, here the plasma membranes and the tonoplasts, down a water concentration gradient. This is the principal mechanism by which water is transported into or out of plant cells. The osmotic pressure of a dilute solution is conventionally calculated by the van't Hoff equation [37]. This formula connects the osmotic pressure to the product of the molarity of the solute, the dimensionless van't Hoff factor, the gas constant and the absolute temperature. Thus, a difference in temperature between two solutions on either side of a semi-permeable membrane will result in an osmotic gradient and a flow of water, from the colder towards the warmer area, until the balance in osmotic pressure is reached. As can be seen on Figure 6, this 
osmoregulation causes the plasma membranes to peel away from the cell walls, a process known as plasmolysis.

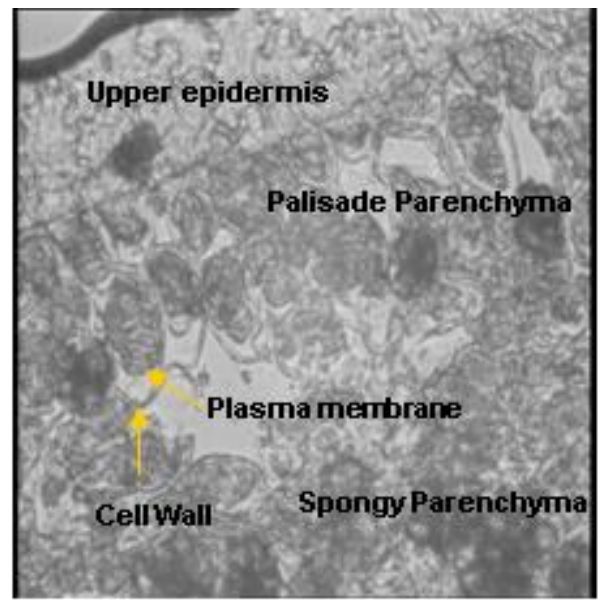

Figure 6 - Photograph of the vegetable cells after fractionation in the TAMD process, $x 400$

In experiments, such local temperature gradients cannot be highlighted. Only the temperature gradient at the press cake boundaries can be measured. To follow the rise in temperature of the press cake, a thin temperature sensor was inserted and placed on the top of the filter media. The variation of the temperature over time at the base of the alfalfa press cake, dewatered with a piston temperature set to $55^{\circ} \mathrm{C}$, is plotted in Figure 7 . The temperature of the bottom part of the press cake increases to a maximum value of $50^{\circ} \mathrm{C}$ after two hours and a half. It is also noticed that, in the same time, the green juice mass tends towards an asymptote. With a wall temperature of $70^{\circ} \mathrm{C}$, the increase in temperature is faster and the bottom part of the press cake reaches $50^{\circ} \mathrm{C}$ after 15 minutes and the maximum temperature of $66^{\circ} \mathrm{C}$ after only 20 minutes. This information is also important for the juice quality. Indeed, some of its components, like the green "hydrophobic" proteins, have a low resistance to thermal treatments [38]. 


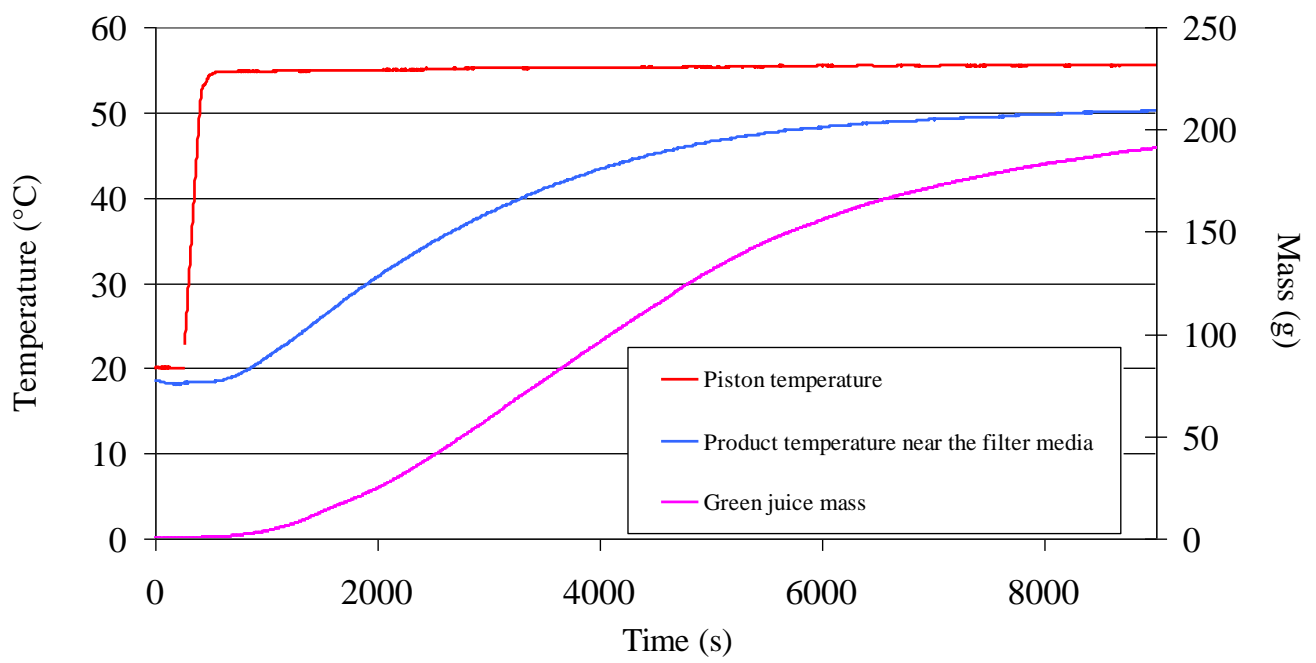

Figure 7 - Evolution of the press cake temperature and green juice mass during the mechanical fractionation of alfalfa $\left(\mathrm{T}_{\text {piston }}=55^{\circ} \mathrm{C}\right)$

\subsection{Assessment of the TAMD process efficiency}

The optimal operating conditions for an efficient separation known, the performances of the TAMD process could be compared to those of the conventional process. Traditionally, juice extraction involves mechanical pulping followed by pressing. At the lab scale, the chops were macerated in a blender. 200gr of pulp was then introduced in the compression cell and dewatered at $300 \mathrm{kPa}$ and ambient temperature.

\subsubsection{Fractionation kinetics with a conventional process}

The fractionation kinetics of the minced and chopped alfalfa, dewatered at ambient temperature, are reported in Figure 8. As expected, pulping affects the amount of green juice extracted from alfalfa: the mass is enhanced by $717 \%$ after one hour of processing. Moreover, the juice flows out almost immediately: for instance, $85 \%$ of the juice is recovered after 15 minutes. The duration of this dwell time is in accordance with former results [39] and common practices. 


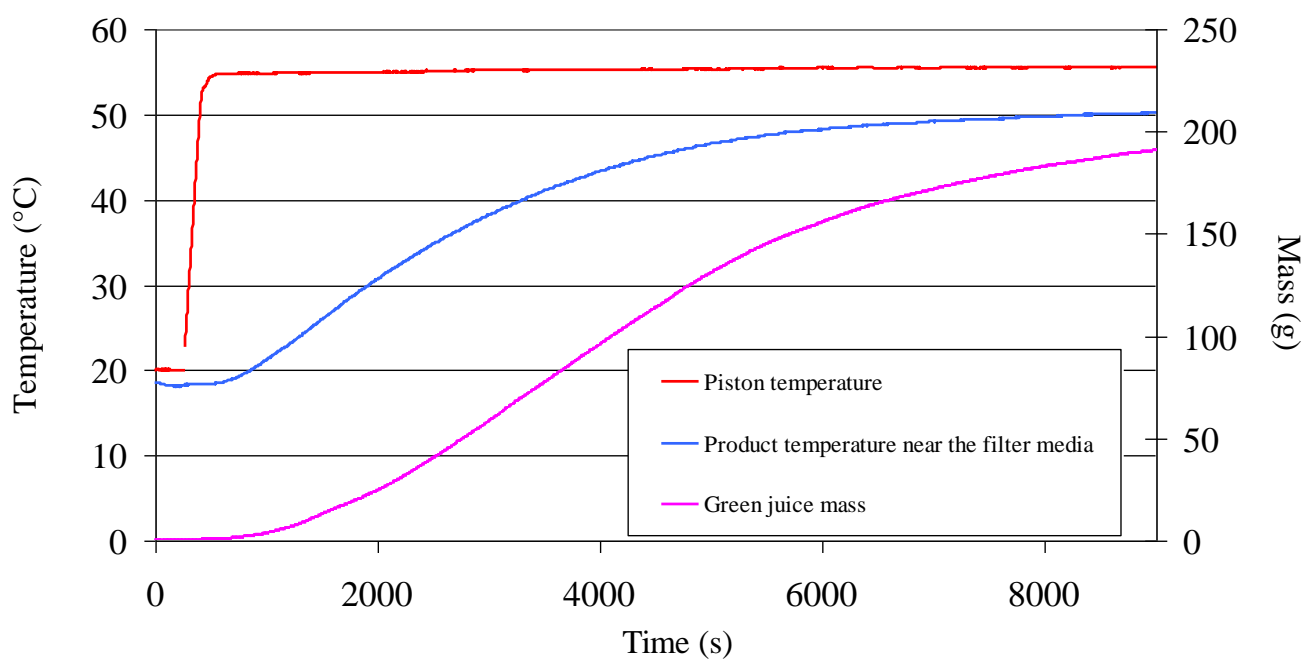

Figure 8 - Comparison of the dewatering kinetics by pressing at ambient temperature, with pulping prior to pressing at ambient temperature and with the TAMD process.

\subsubsection{Comparison of the extraction yields}

To assess the performances of the TAMD process, alfalfa cut in $5 \mathrm{~cm}$ pieces was dewatered with the TAMD process, whose piston temperature was heated to $70^{\circ} \mathrm{C}$. The corresponding fractionation kinetic is plotted in Figure 8. The maximum amount of green juice extracted with these operating conditions is higher than that produced with the conventional process even if the initial extraction velocity is slower. Nevertheless, after 15 minutes of processing, the recovered mass of green juice is identical. To compare the results, an extraction yield, defined as the ratio of the mass of green juice produced after one hour of pressing to the mass of the liquid intrinsically introduced, is reported in Table 4. As expected, the extraction yield for a pressing, preceded by a mechanical pulping, is close to 55\%. For the TAMD process operating at $300 \mathrm{kPa}$ with a piston temperature set to $70^{\circ} \mathrm{C}$, the extraction yield amounts to $69 \%$, that is to say an increase of $23 \%$. For the TAMD process operating at $300 \mathrm{kPa}$ during one hour with a piston temperature set to $50^{\circ} \mathrm{C}$, the extraction yield is $53 \%$. If the dewatering time is increased to one hour and a half, the extraction yield rises to $69 \%$. Indeed, the mass of green juice produced is roughly the same as shown in Figure 5. For a wall temperature lower 
than $70^{\circ} \mathrm{C}$, the time of dehydration must be significantly longer than that conventionally used to obtain a larger quantity of juice.

\begin{tabular}{|l|c|c|}
\cline { 2 - 3 } \multicolumn{1}{c|}{} & $\begin{array}{c}\text { Extraction } \\
\text { yield at } 1 \mathrm{~h} \\
(\%)\end{array}$ & $\begin{array}{c}\text { Final solid } \\
\text { content of the } \\
\text { cake after } 1 \mathrm{~h} \\
(\%)\end{array}$ \\
\hline Pressing at $30^{\circ} \mathrm{C}$ & 7.8 & 18.3 \\
\hline Pulping prior to pressing at $30^{\circ} \mathrm{C}$ & 55.9 & 31.8 \\
\hline TAMD process with $\mathrm{T}_{\text {wall }}=70^{\circ} \mathrm{C}$ & 69.0 & 41.1 \\
\hline
\end{tabular}

Table 4 - Extraction yield for pressing at ambient temperature, for pulping prior to pressing at ambient temperature and for the TAMD process set to $70^{\circ} \mathrm{C}$

\section{Summary}

The TAMD process was used to efficiently dewater 'nature-wet' biomass like spinach leaves and alfalfa stems and leaves. The influence of cutting, pulping and heating conditions on the dewatering kinetics and the extraction yield were investigated. The influence of the pressure applied was not considered in the present paper. It has been illustrated that a mechanical pulping, performed at the lab scale using a blender, has a much greater influence both on the maximum amount of green juice extracted and on the extraction velocity than cutting. Only a relatively fine cutting $(0.5 \mathrm{~cm}$ broad bands in the present study) increases significantly the quantity of green juice recovered. As a result, the dry solid content is enhanced from 2 to $5 \%$ at best, for an applied pressure of $300 \mathrm{kPa}$. The heating conditions have much more influence on the extraction. For an applied pressure of $300 \mathrm{kPa}$, the TAMD process can be used to remove $69 \%$ of the inherent water from alfalfa under moderate heating conditions, the enhancement being of $55 \%$ in a conventional dewatering process with prior pulping. With a piston temperature set to $70^{\circ} \mathrm{C}$, the duration of the mechanical fractionation must be at least 30 minutes. If the piston temperature is decreased to $50^{\circ} \mathrm{C}$, a longer pressing time, at least one 
hour and a half, is required. Beyond $70^{\circ} \mathrm{C}$, the temperature does not have any influence on the extraction kinetics. The temperature gradient in the press cake is supposed to generate a difference in osmotic pressure in the biomass, which induces a flow of green juice through the membrane walls, until the balance in osmotic pressure is reached. This assumption will have to be confirmed by future work. The first question, which arises at this stage of the process design, relates to the heat supply on the composition of the green juice produced. Indeed, the face of the press cake in contact with the filtering medium increases rapidly to $50^{\circ} \mathrm{C}$ and it is well-known that some of the proteins precipitate at low temperature. The second question concerns the specific energy consumption of the TAMD process and the cost of the separation. These two items will be discussed in future publications.

\section{Acknowledgments}

This work has been partially supported by the French National Agency (ANR) in the frame of its Technological Research CP2D program (Produluz, project nºNR-07-CP2D-16-02). The authors would like to acknowledge Bernard AUDUC for its technical assistance in the construction and development of the experimental set-up.

\section{Bibliography}

[1] Biomass R\&D technical Advisory Committee, Roadmap for biomass technologies in the United States, http://www.brdisolutions.com/pdfs/FinalBiomassRoadmap.pdf, 2002

[2] European Parliament and Council, Towards a European strategy for the security of energy supply, Green Paper COM/2002/0321, European Parliament, Strasbourg, 2002.

[3] National Research Council, Biobased industrial products, priorities for research and commercialization, National Academic Press, Washington D.C., 2000.

[4] B. Kamm, M. Kamm, Principles of biorefineries, Appl. Microbiol. Biotechnol. 64 (2004) $137-145$ 
[5] W. Soetaert, Defining biorefinery and different concepts, Second annual European Biorefinery Workshop, http://www.biorefinery-euroview.eu/biorefinery/public/documents/ \%284_\%29\%20Wim_Soetaert_presentation_BioreFuture_2009.pdf, 30 ${ }^{\text {th }}$ March 2009.

[6] R. Hatti-Kaul, Biorefineries - A path to sustainability ?, Crop Science 50(2010) 152-156.

[7] A.S. Jones, The principles of green crop fractionation, in R.J. Wilkins (Ed.), Green Crop fractionation - Symposium Proceedings of the British Grassland Society and the British Society of Animal Production, Harrogate, 1976, pp. 1-7.

[8] L. Telek, Leaf Protein Extraction from tropical plants, In US Congress (Eds.), Plants : the Potential for Extracting Protein Medicines and Other Useful Chemicals, Washington D.C., 1983, pp. 78-125.

[9] N.W. Pirie, Leaf protein after forty year, BioEssays. 5(1986) 174-175.

[10] S. Kromus, B. Wachter, W. Koschuh, M. Mandl, C. Krotscheck, M. Narodoslawsky, The green biorefinery Austria - Development of an integrated system for green biomass utilization, Chem. Biochem. Eng. Q. 18 (2004) 7-12.

[11] B. Kamm, P.Schönicke, M. Kamm, Biorefining of green biomass - technical and energetic considerations, Clean 37 (2009) 27-30.

[12] F. Richter, R. Gra $\beta$, T. Fricke, W. Zerr and M. Wachendorf, Utilization of semi-natural grassland through integrated generation of solid fuel and biogas from biomass. Part II. Effects of hydrothermal conditioning and mechanical dehydration on anaerobic digestion of press fluids, Grass and Forage Science 64 (2009) 354-363.

[13] H.G. Walker, G.O. Kohler, W.N. Garrett, Comparative feeding value of alfalfa press cake residues after mechanical extraction of protein, Journal of Animal Science 55 (1982) 498-504.

[14] M. Wachendorf, F. Richter, T. Fricke, R. Gra $\beta$, R. Neff, Utilization of semi-natural grassland through integrated generation of solid fuel and biogas from biomass. Part I. Effect 
of hydrothermal conditioning and mechanical dehydration on mass flows of organic and mineral plant compounds, and nutrient balances, Grass and Forage Science 64 (2009) 132143.

[15] S. Sinclair, Protein extraction from pasture. Literature Review Part A: The plant fractionation bio-process and adaptability to farming systems, http://www.maf.govt.nz/sff/about-projects/search/C08-001/literature-review.pdf , 23 august 2009.

[16] M.A. Hanna, R.L. Ogden, Expression of alfalfa juice, J. of Agric. Food Chem., 28 (1980) 1212-1216.

[17] R.H. Edwards, D. de Fremery, R. Miller, G.O. Kohler, Pilot plant production of alfalfa leaf protein concentrate, Chem. Eng. Prog. Symp. Ser. 24 (1978) 158-166.

[18] R.G Koegel, R.J. Strauss, Fractionation of alfalfa for food, feed, biomass and enzymes, Transactions of the ASAE 39 (1996) 769-774.

[19] N. Grimi, I. Praporscic, N. Lebovka, E. Vorobiev, Selective extraction from carrot slices by pressing and washing enhanced by pulsed electric fields, Separation and Purification Technology 58 (2007) 267-273.

[20] T. Gachovska, M.O. Ngadi, G.S.V. Raghavan, Pulsed electric field assisted juice extraction from alfalfa, Canadian Biosystems Engineering 48 (2006) 33-37.

[21] E.S. Tarleton, The role of field assisted techniques in solid/liquid separation, Filtration\&Separation (1992) 246-252.

[22] S. Isobe, F. Zuber, E. Manebog, L. Lite, K. Uemura, A. Noguchi, Solid-Liquid separation of agricultural products using twin screw press and electro-osmosis, JARQ 31 (1997) 137146. 
[23] S.A. Clayton, O.N. Scholes, A.F.A. Hoadley, R.A. Wheeler, M.J. McIntosh, D.Q. Huynh, Dewatering of biomaterials by mechanical thermal expression, Drying Technology 24 (2006) 819-834.

[24] A. Mahmoud, P. Arlabosse, A. Fernandez, Application of a thermally assisted dewatering process to biomass, Biomass and Bioenergy (2010), doi:10.1016/j.biombioe.2010.08.037.

[25] W. Koschuh, V.H. Thang, S. Krasteva, S. Novalin, K.D. Kulbe, Flux and retention behaviour of nanofiltration and fine ultrafiltration membranes in filtrating juice from a green biorefinery, J. of Mem. Sci. 261 (2005) 121-128.

[26] Y. Bai, C.E. Glatz, Bioprocess Considerations for Expanded-bed Chromatography of Crude Canola Extract: Sample Preparation and Adsorbent Reuse, Biotechnol. and Bioeng. 81 (2003) 775782.

[27] S. Kerfai, A. Fernandez, S. Mathé, S. Alfenore S., Procédé d'échange d'ions en lit expansé : application a la récupération des protéines hydrophiles du jus de Luzerne (expanded-bed chromatography for one-step purification of soluble proteins in alfalfa juice), Récents Progrès en Génie des Procédés, 98 (2009), in French.

[28] Arlabosse P., Fernandez M.A., Auduc B. and A. Mahmoud, Procédé de Déshydratation assistée thermiquement, Patent FR 2923 587, November 2007.

[29] J. Guo, S. Hodges, P.H.T. Uhlherr, Dewatering of HTD coal slurry by mechanical expression, Coal Preparation 18 (1997) 227-239.

[30] C. Bergins, Kinetics and mechanism during mechanical/thermal dewatering of lignite, Fuel, 82 (2003) 355-364.

[31] S.A. Clayton, R.A. Wheeler, A.F.A. Hoadley, Pore destruction resulting from mechanical thermal expression, Drying Technology, 25 (2007) 533-546. 
[32] S. Kerfaï, A. Fernandez, S. Mathé, S. Alfenore, P. Arlabosse, Production of green juice with an intensive thermo-mechanical fractionation process. Part 2: Effects of the processing conditions on the liquid fraction properties, submitted to J. Chem. Eng.

[33] A. Mahmoud, A. Fernandez, P. Arlabosse P, Thermally-Assisted Mechanical Dewatering (TAMD) of Suspensions of Fine Particles: Analysis of the influence of the operating conditions using the response surface methodology, Chemosphere 72 (2008) 1765-1773.

[34] W.G. Hopkins, N.P. Huner, Introduction to Plant Physiology, Wiley John and sons (Eds.), $4^{\text {th }}$ edition (2009) 528p.

[35] B.E.S Gunning, M.W. Steer, Plant cell biology- Structure and function, Jones and Bartlett Publishers (1996) 144 p.

[36] P. Savoie, S. Beauregard, Predicting the effects of hay swath manipulation on field drying, Transactions of the ASAE 33( 1990) 1790-1794

[37] P.J. Kramer, J.S. Boyer, Water relations of plants and soils, Academic Press, Inc., San Diego, 1995.

[38] J.D. Dilly, O. De Mathan, L'extraction des protéines de luzerne (Extraction of alfalfa proteins), Industries Agricoles Alimentaires 2 (1978) 65-72, in French.

[39] R.D. Holdren, W.L. Harris, G.J. Burkhardt, Squeezing juice from forage, Transaction of the ASAE 15 (1972) 1044-1048. 